Mansoura Enginecring Journal, (MEJ). Vol. 31, No. 4, December 2006.

\title{
ENHANCING MIXED CONVECTION HEAT TRANSFER FROM MULTIPLE PROTRUDING HEAT SOURCES USING INCLINED OBSTACLES
}

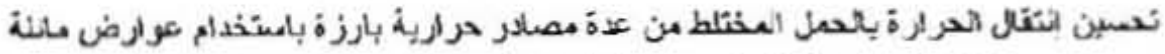 \\ Mahmotid. M. Awad, Gamal. I. Sullan. and Wuleed A. El-Awaty \\ Mechanical Power Engineering Department. \\ Mansoura Universiiy. Mansoura 355 16. Fgypt \\ Email: gisuitan@mans.cdu.c:
}

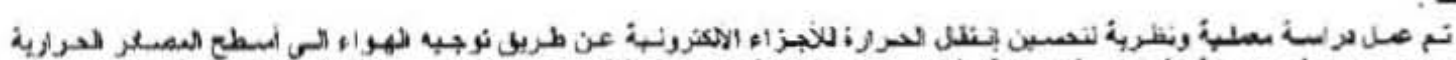

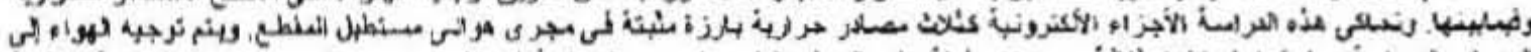

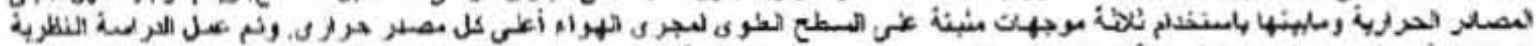

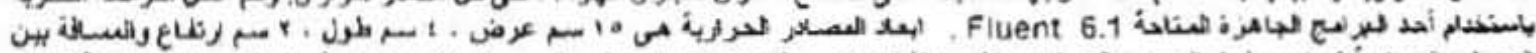

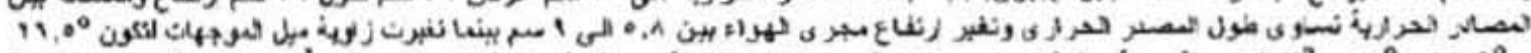

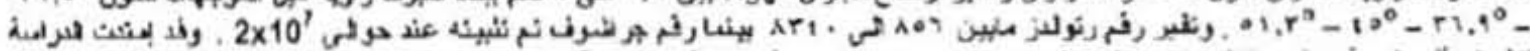

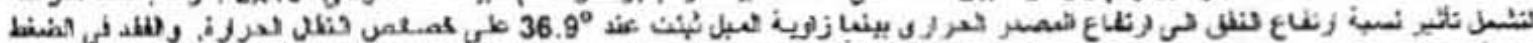

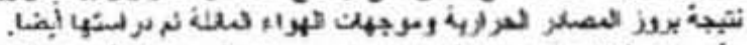

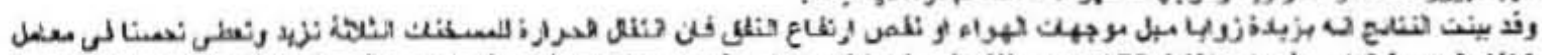

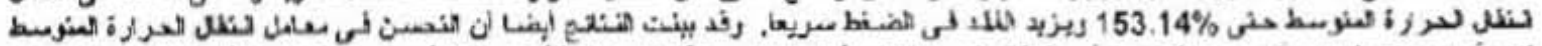

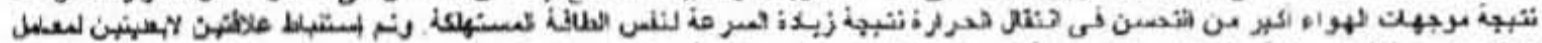

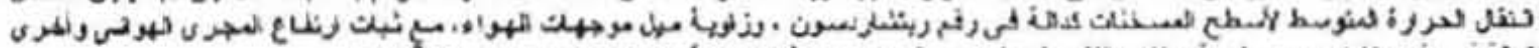

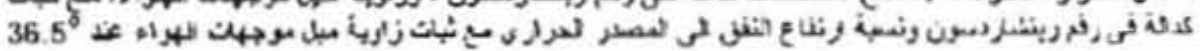

\begin{abstract}

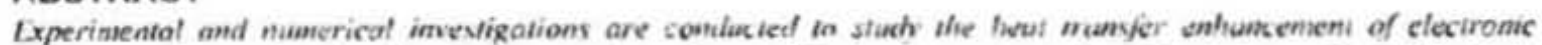

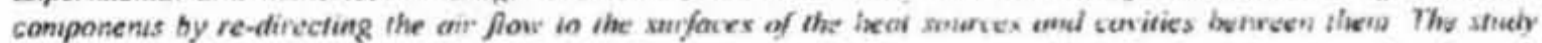

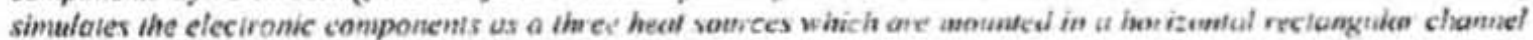
The fow is re-directed to the heat sources asing three inclined obetiater abon the heut suarces in order to urient the flow 10 boih the closed cavity regions and heat sources surfaces The manericat investigation is conducted usank

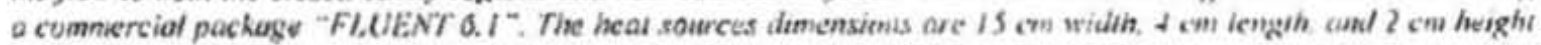

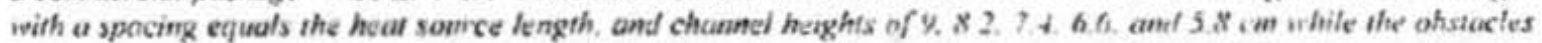

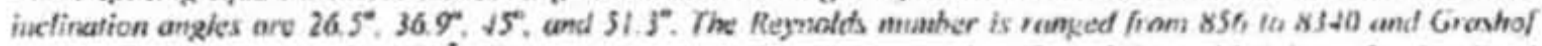

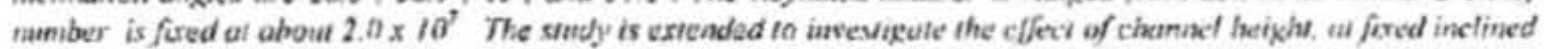

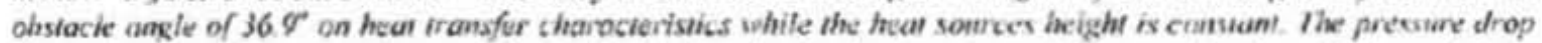

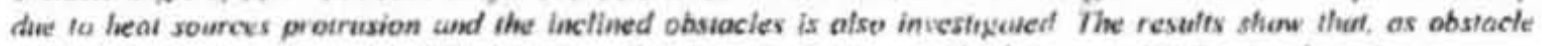
angie increases or channel heigit decreases (height ratio increases) the lucul thansfur for the three heat sources

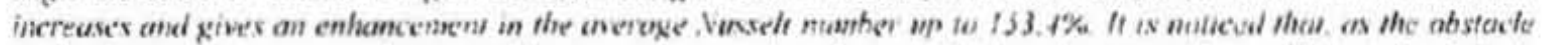

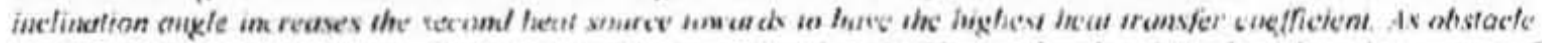

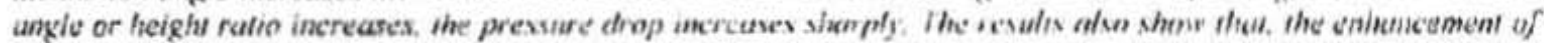

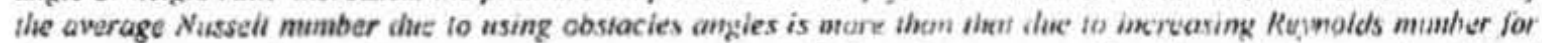

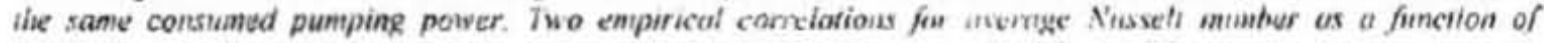

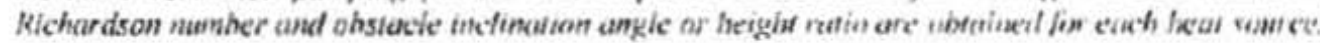

Keywords: Electronic cooling. protruding heat sources, heat transfer

\section{INTRODUCTION}

During the last decades, the trend in electronic industry has been lotvards muniaturization, which has lead to an iacrease in package-level heat fluxes while the temperature linits have remained unchanged. As demands on the perfomance and packaging of elecironic assemblies contimually increasc, the problem of thernat management beconcs more challenging. The impaci of the emperature on systen reliability was shown in surves condected by the United States Air Force. which ieporiet that temperature is contributed to nore than $50 \%$ of all clectronic failure (Sergent and $\mathrm{AI}$ Krum (1)). Numcrous experimental and nunicrical invesligatious on heat iransfer enhancements in 


\section{70 Mahmoud M. Awad, Gamal 1. Sultan \& Walced A. El-A wady.}

electronic modules by using differem cooliag iechnigues, have been reponed. Sathe and Sanumakia 121. presented a review of recent developments in some practical sapests of air-cooled electronic packages. Habehi and Acharyn |3| investigated numerically the taminar mixed convection heat transfer in a vertical channel coebaining a partial rectangular blockage. Rahman and Raghavan [4], earried out o numerical simulaticn of heal transfer during sross-flow mixed convection in electronic circuit boards. Wang and Vafai [5]. presented an experimental investigation of convective heat trassfer and preanure loss in a rectangalar channet with ditcrete Mash-moenied and protruding heat soorses. Sultan 16]. studied experimentally the forced tonvection heat transfer of multiple protruding heat sourses with pansive cooling. Iwia et al. [?]. studied numerically the effect of the doct apect ratio on hear transfer of the how over a backward-facing step at low Reynolds number. Sparrow and Hossfeld [8], studied experimentally the effect of rousding the protruding edges on heat transfer and pressure drop. Jubran and Al.Haroun $[9]$. studied experimentally the effect of secondary air injection bole arrangements on the heat iransfer coefficient and the pressure drop characteristick. Oue and Sharif [10]. simulated numerically mived coovective head transfer in a rectangutar cavity with consant heat from partially heated botbom wall while the iscthermal side walls were moving in the vertical direction. Dogan et at. [II]. investigated experimentally the miced convestion heat transfer in a top and bottom beried reciancular channel whit dikcrete hea sources. Sulin |12] and Carimella and Eibeck $[13]$ iaventigated evperimentally the effect of spanwise spacing on de heat transfer from an array of protruding clements in forced convection. Sparrow et aL. [14]. investigated cxperimentally the effect of implemented barrien in arrays of rectangular modules and reported sienificant improvement in the heat iranifer coefficient of the module in the second row downstream of the barrier. Carimelis and Eibeck [15] uvdied experimentally the ratent of heat unsfer enhancement obtained by introducine vones jemernten wpatrean of an inline array of beated peonuding elementi. Wu and Perne [16] presensed a numerical investigation on heat tranafer enhancement of mised convective fow by instaflation of an eblique plate for internal fow modification induced by vones sheddine. Many investigations were dirested io conjugate heat iranifer modes. where the eflects of spendustioe and convection heat inasfer are Mudied [17.21]. For canvective heat srasifer, many different fluids are uned as a workine flaid. Carimella and Eibeck [22] Dhowmik et al $[23 \mid$ used water as a working flaid while Two et al. $[24]$. Bhowinik and Tou [25] used fleorocarbons (FC-72) for a bighty heat flus rate.
The aim of this work is to simalate cooling of electronic equipments experimentally and numerically to investigate mised convective heat tramsler from multiple protruding heat sources and sudy the effect of obstacles angle which re-direct the flow lowarts the surfices of the heat sources and the cavities between heai sources. The study is exiended to study the effect of chanael height variation, at fixed inclination angle. on cooling of the heat sources, and pressure loss analysis is alvo presented.

\section{Experimental test-rig}

The schematic diavan of line experimental iesteris including the test section is shown in Figs. 1 and 2 . The Ient section (1) of $90 \mathrm{~cm}$ lone with cross sectional arts of $15 \times 9 \mathrm{~cm}$ is inade from wood. The sir is withdrawn by the blower (iv) which eaters the test section dirough a bell mouth ialet and fie wesh screen (2) to iasure uniform flow with a nesligible surbalence. Thee typically hea sourves (4) are mounted on the base plate of the ies section with spacine ratio $S / L=1$. The firsi beat sourse is located at $L_{-}=43 \mathrm{~cm}$ from the catrance of the channel. The heating element of each heat source is a eickej-ehromium wire (5) which is wrapped at equal pitches over a ceramic core $(6)$ of $3.5 \mathrm{~cm}$ lengsh, $1.5 \mathrm{~cm}$ beight and $15 \mathrm{~cm}$ wihlih. Each core is surrounded by a $0.5 \mathrm{~mm}$ thickenss mica-sheet $(7)$. and is inserted inside an sluminum chanel $(8) .4 \mathrm{~cm}$ length fin the flow direction). 2 cin heighe, and $15 \mathrm{~cm}$ width to form the three protrading heat sources. Three inclined obutacles of woodea aneles haviag differeas inclination $126.6^{\circ}$. $36.9^{\circ}, 45^{\circ}, 31.37$ ) are iasalied below the upper plate of the ies section and above the tiree heal sources io redirect the air flow io the closed eavities beiween each fwo heat seuress to investigate the effect of obstacles angle on the heat iransfer cooflicient.

To conitrol the hea inpet to each heat source and insure that each beat source emits approsinuately the same heat flux, each heat souree is sevipped with a variac iramformer $(10)$ as well as an ammeter (11). which has an accuracy of $+0.1 A$ and o voltmeter $(12)$ with an aceuracy of $+1.2 \%$ of the reading. The surface temperature of each heat source is measured by nine calilrated coport-constantan thermocouples (13) which are glued well on the imvide surface of the alumimum chanoel by means of high thermal conductivity epoxy. Alao, the iemperature disuribution along the iest section floor is meanured by ten thermocouples (two thermocnuples are distributed between cach two heat sources. Hirce in fnum of the first heat source and another three behind the last heat sovircel. The inlet air temperature is mecusered by a thermocouple located at the air flow inlet. Aluo, the temperature above each beat source is measured by a thermocouple passing through the inclined ebstacle. 
1. Test section

2. Mesh sereen

3. Bell mouth Inle1

4. Ilext sources

5. Nickel-Chromiam wire

Cerumic core

7. Mich sheet

8. Alumlnum charine!

9. Thermocouples

10. Vuriac

II. Ammeter

12. Voltmeter

13. Thermocouples

14. Temperature recorder

is. Orifice neter

16. Llube mnnometer

17. Pressure taps

18. Glass wool insulation

19. Air blowe

20. Gate plate

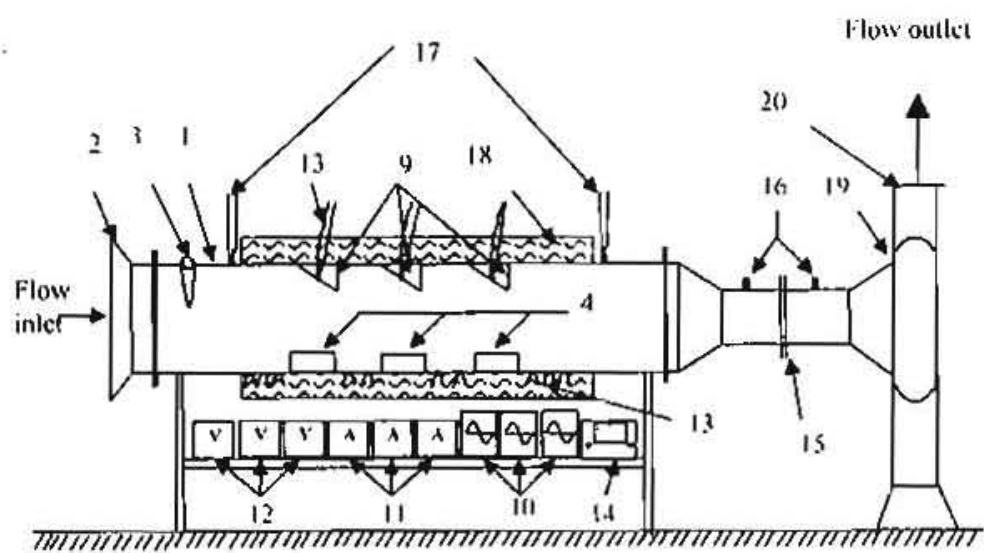

Figure 1. Schematic diagram of the experimental test-rig

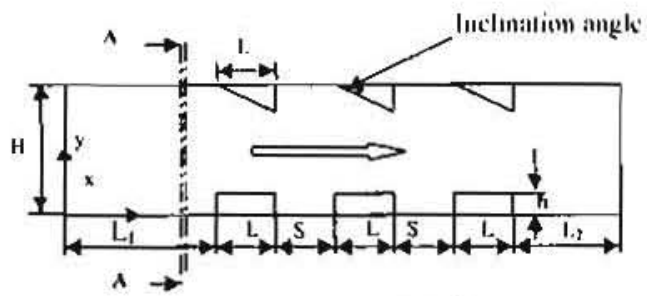

Fig.(2.3)

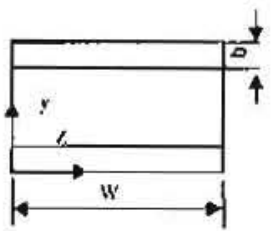

Figuce 2. Details of the test rig

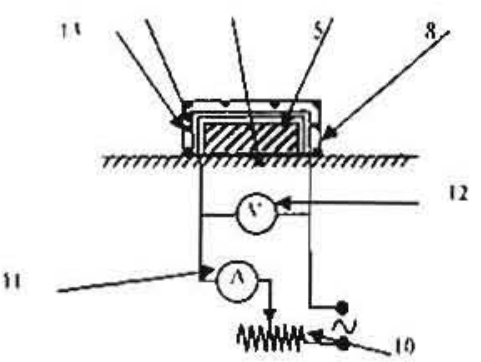

lig(2-b)

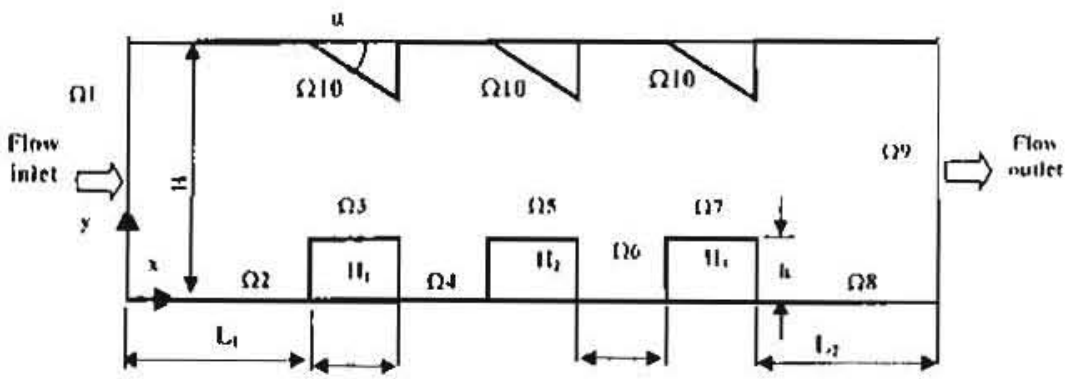

Figure 3. Problem Physical description and boundary conditions.

The thcrmocouples are connected to a digital temperature recorder $(14)$ which has an accuracy less than $\pm 1 \%$ with the aid of two multi-switch points selectors.

The average flow velocity is measured by the help of an orifice meter (15) with the aid of U-tube manometer
(16). The pressure drop due to the protruding heal sources and the attached inclined obstacles is measured by a U-tube manonieter which connected to pressure taps (17) as shown in Fig. 1.

The test section is covered by a glass wool insulation (18) $(40 \mathrm{~mm}$ thick) to reduce the heat loss from the tes section walls to the surroundings to a negligible value. 


\section{72 Mahmoud M. Awad, Gamal l. Sultan \& Walced A. El-Awady.}

To study the effect of channel height variation with using inclined obstacles, the channet height. $\mathrm{H}$. has the values, 9.0,8.2,7.4, 6.6. and $5.8 \mathrm{~cm}$, and the heat source height is fixed at $2 \mathrm{~cm}$. These channel heights lead to height ratios. HR. of $0.222,0.244,0.27 .0 .303$. and 0.345 . The angle of the inclined obstacles is fixed at $39.6^{\circ}$ when studying the effect of height ratio. Nearly two hours are needed to reach the steady state condition, which is recorded as the temperature reading did not change with time

The connective heat fux $q^{*}$ is determined from the electrical power input to each heat source using:

$$
q^{*}=\frac{V i}{(i . \cdot 2 b) W}
$$

Reynolds number and Grashof number. which based on the heat source iength $L$, are defined as:

$$
\begin{aligned}
& R c_{1}=\frac{\rho_{A} \|_{m} L^{\prime}}{\mu_{A}} \\
& \mathrm{Gr}_{1 .}=\frac{g \beta q^{\prime \prime}(1 .+2 h) L^{\prime}}{\lambda v^{2}}
\end{aligned}
$$

The results are presented in terms of the dimensionless temperature $\theta_{1}$, average Nussclt number. Richardson number as follow:

$$
0_{1}=\left(\frac{T_{i}-T_{0}}{q^{*} L / \lambda}\right) G r_{1}^{(2)}
$$

The heat transfer coefficient and Nusselt number is defined as:

$$
\begin{aligned}
& h_{v}=\frac{q^{\prime \prime}}{\left(T_{1}-T_{a}\right)} \\
& h_{a v}=\frac{1}{t+2 h} \int_{0}^{L+2 b} h_{x} d x
\end{aligned}
$$

Where $T_{2}$ is air temperature above the heat source. ${ }^{\circ} \mathrm{C}$

$$
\begin{aligned}
& N_{w}=\frac{h_{0} !}{2} \\
& \mathbf{R} \mathbf{i}=\frac{\mathrm{Gr}_{\mathbf{L}}}{\mathrm{Re}_{\mathrm{1}}{ }^{\mathrm{l}}}
\end{aligned}
$$

The friction factor and power consumed are as follow:

$$
\begin{aligned}
& \mathrm{P}=\frac{\Delta \mathrm{P}_{\text {drop }}}{\frac{1}{2} P_{\mathrm{A}} \mathrm{U}_{m}^{2}} \\
& \mathrm{P}_{\mathrm{C}}=\dot{V} \Delta \mathrm{P}_{\text {drOD }}
\end{aligned}
$$

\section{Numerical model}

All computational results presented in this paper are obtained with the commercial CFD code FLUENT 6.1. The now throughout computational domain is considered to be steady state, incompressible. turbulent. Iwo-dimensional flow in the $x-y$ plan. with constant properties.

\subsection{Governing equations}

Numerical analysis is based on the Reynolds-averaged Navier Stokes equations. The continuity. momentum. and energy equations are used as followed:

$\frac{a_{(p u, 1}}{r_{x_{1}}}=0$

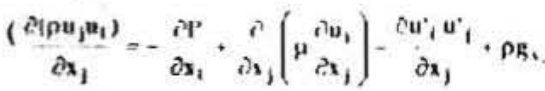

$\frac{\partial\left(\rho p_{1} N\right)}{\partial_{v_{1}}}=\frac{\dot{r}}{\partial_{s_{1}}}\left(1 ; \frac{r_{1}}{r_{s_{1}}}\right) \cdot \mathrm{S}_{1}$

To close the Reynolds-averaged Navier Stokes equations, the Reynolds stresses " " , which represent the turbulence effects, are modeled using the standard $k$ $\varepsilon$ model as lollowed:

$$
\begin{aligned}
& \frac{\partial\left(\rho u_{j} k\right)}{\partial x_{j}}=\frac{\partial}{\partial_{x_{j}}}\left[\left(\mu \cdot \frac{\mu_{1}}{\sigma_{2}}\right) \frac{\partial k}{\partial_{x_{j}}}\right] \cdot c_{a_{b}} \cdot G_{b_{1}} \cdot \partial \varepsilon
\end{aligned}
$$

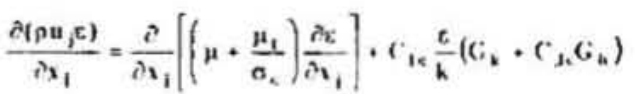

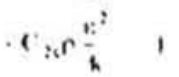

$$
\begin{aligned}
& \mu_{1}=\rho C_{0}, \frac{h^{2}}{r:}
\end{aligned}
$$

$C_{1 x} C_{2 x}$ are constants, have the values as shown in table (1), and $\mathrm{C}_{4}$, is calculated from the relation, [29]:

$r_{x}=\operatorname{lanh}\left|\frac{\mathrm{v}}{\mathrm{u}}\right|$

Tabie t. The turbulent model constants

\begin{tabular}{|c|c|c|c|c|c|}
\hline$C_{16}$ & $C_{2 .}$ & $\sigma_{k}$ & $\sigma_{c}$ & $P_{r_{i}}$ & $C_{v}$ \\
\hline 1.44 & 1.92 & 1.3 & 0.9 & 1 & 0.09 \\
\hline
\end{tabular}

The above governing equations are solved for temperature, pressure. velocily. kinetic energy (k), and dissipating rate $(\varepsilon)$. Furthermore, the average Nusselt number. pressure drop, and stream function can be compuied.

\subsection{Problem domain}

The physical description of the problem under investigation is illustrated in Fig. (3). The flow is considered two-dimensional fow in $x-y$ plan. Protruding heal sources are represented by three blocks, $0.04 \times 0.02 \times 1 \mathrm{~m}$, with an intermediate spacing equals 
to heat source lengith placed on the floor of a reciangular channel of $1.5 \mathrm{~m}$ long. $1 \mathrm{~m}$ depth and its height varied from 0.09 10 $0.058 \mathrm{~m}$. The entrance channel length $L_{0}$ is aboul $0.43 \mathrm{~m}$ where the exit length is $0.87 \mathrm{~m}$. Three inclincd obstacles are presented above the three heat sources with inclination angle ranged from $0^{\circ}$ to $51.3^{\circ}$

\subsection{Boundary conditions}

The various boundaries that bounded the problem domain are illustrated in Fig. (3) and named as $\Omega$ i. Dependant variables have to be specified or its derivatives on the domain boundaries as follow:

(i) At inlet ( $\Omega 1): 0.34 \leq u(0 . y) \leq 3.4 \mathrm{~m} / \mathrm{sec}, v(0 . y)=0$. $T(0, y)=300 \mathrm{~K}, 0.1 \mathrm{I} \leq \mathrm{D}_{\mathrm{h}} \leq 0.165 \mathrm{~m}$. turbulent intensity $=1.15 \%$

(ii) At the walls $(\Omega i, i=2,4.6 .8$, and 10$): u(x, y)=0$. $v(x . y)=0 . q=0 . k=0$ and $c=0$.

(iii) At the walls ( $\Omega \mathrm{i}, \mathrm{i}=3.5$, and 7 ) (heat sources lop and sides surfnces): $u(x, y)=0, v(x, y)=0, q^{\prime \prime}-1240 \mathrm{~W} / \mathrm{m}$ : $k=0$ and $\varepsilon=0$.

(iv) At the exit (29): outiet flow. the boundary conditions at the exit are adjusted (by the CFD code) such that the properties gradient at the exit equal to zero.

\section{Results and discussions}

\section{4.) Temperature distribution}

Thie variation of local surface temperature difference along each heat sources at different Reynolds numbers ranging from 850 to 8340 . constant $G r_{L}=2.0 \times 10^{\prime}$ and spacing ratio $S / L-1$ is shown in Fig. (4). It is noticed that, the local surface temperature decreases with increasing Reynolds number and the surface temperature for the first beat source is less than that of the second one and the second heat source is less than the third one. for all Reynolds numbers and this agree well with Sultan [12],

Figure ( $\$$ ) shows the influence of Reynolds number on the maximum temperature of the three heat sources. It is clear that the maximum teinpcraturc decreases with increasing of Reynolds number and this agree well with Sultan [12].

\subsection{Heat transfer}

Figure (6) presents the behavior of the average Nusselt number with Reynolds numbers for the three heat sources. As expected, as the Reynolds number increases. the average Nusselt number for the heat sources to the fluid increases. It is clear that the first heal source has the highest Nusselt number and the third heat source has the lowest values for the studied rang of Reynolds numbers.

\subsection{Efrect of obstacle inclination angle}

Figure (7) shows the effect of flow directing angle $\{a\}$ on local temipernture difference along the heal sources at different values of Reynolds numbers.

It is noticed that, when the flow obstacles inclination angle increases. the local temperature difference of the second heat source decreases than that of the first heat source as Reynolds number increases. Also for obstacles inclination angle $\left(\alpha-51.3^{\circ}\right)$. the local temperature difference of the second heat source is small than the first and the third for all studied Reynolds numbers.

To show the effect of obstacles inclination angle on heat transfer cocfficient. the average Nusselt number is plented against obstacles inclination angle $(a)$ as shown in Fig. (8).

II is noticed that. for Reynolds number. Re $\leq 4200$, the effect of inclination angle $(a)$ is not significant for smail angle $\alpha \leq 26.5$ for the three heat sources. but for $\alpha>26.5^{\circ}$. a valuable increase in Nusselt number is observed. For high Reynolds numbers Re>4200. a significant increase of Nusselt number with increasing inclination angle is observed for all inclination ang/es. In addition, the curves show that for $\alpha \leq 36.9$ and $R e \leq 2345$. first heat source has the highest Nusselt number. For Re 21480 and $a \geq 36.9$. Ihe second heat source has the bes: heal Iransfer.

Figure (9) shows the enhancemitnt of the average Nusselt number with respect io Reynolds number. It is observed that, at Re $\leq 1480$ and obstacles inclination angle $(\alpha-26.5)$. there is no enhancement of the average Nusselt number for the second and third heat sources while the average Nusselt number of the first heat source is improved. For the same obslacles inclination angle and $R e>1480$, all the heal sources has a valuable enliancemcm in the average Nusseh number. Also for the other obstacles angles. all heat sources have an improved heal transfer.

II is obscrved that. the maximum enhancement in average Nusselt number occurred at $R \mathbf{c}=8340$ and $\alpha=\$ 1.3^{0}$ for all the three heat sources: the maximum enhancemenl in average Nussclt number is $49.3 \%$ for the first heat source. $102.1 \%$ for the second heat source. and $81.6 \%$ for the third heat source.

Figure $(10)$ indicates the dependence of average Nussclt number of the three heat sources with Richardson number GriRe for different inclination angles. In the mixed convection dominated now. $\left|<\mathrm{Gr} / \mathrm{Re}^{2}<20 \quad\right| 12 \mid$. the average Nusselt number decreases slighily with increasing Richardson number while for forced convection domimated flow. GRVRe ${ }^{2}<1$. the average Nusselt number decrease dramatically with incrensing Richardson number for all inclination angles. 


\subsection{Effect of channel height at fixed inclination angle}

To study the effect of channel height at fixed inclination angle. on local surface temperature and heat transfer. five channel heights $(H=90,82,74,66$. and $58 \mathrm{~mm})$ are used. Heat sources height is kept constant at $h=20 \mathrm{~mm}$, which leads to height ratio $(H R=h / H)$ of 0.222 .0 .244 . $0.27,0.303$. and 0.345 . All heighis are accomplished by inclination angle of $36.9^{\circ}$. Figure $(11)$ shows the effects of channel height on local temperature difference along the heat sources at different values of Reynolds numbers. h is noticed that. the local temperature of all heal sources decrease as channel height decreases (HR increases). This decreasing may be due to the increase of the flow velocity above the heal sources as channcl height decreased and the turbulent generated by the obstacles inclination angle when approaches to the heat sources surfaces. For $H R=0.222$, the first heat source has the lowest surface temperature for low Reynolds numbers, and the second heat source towards to be the lowest as Reynolds number and HR increase.

To show the effect of channel height variation on heat transiet coefficient. average Nusselt number is plotted against height ratio as shown in Fig. (12). The average Nusselt number increases as Reynolds number increases and/or channel height decreases. It is noticed that. the second heat source has the best heal transfer coefficient. That is because of more lurbulen! generated by the obstacies angles edges. Figure (13) shows the enhancement of the average Nusseli number with respect to Reynolds number al different height ratios. It is observed that. for low Reynolds numbers ( $R e \leq 2097)$ and height ratios ( $+R=0.244$ and 0.27 ), a valuable enhancement in heat transfer for all heat sources from $12.9 \%$ to $37.3 \%$ is observed. For height ratios $(H R=0.303$ and 0.304$)$. the maximum enhancement occurred at high Reynoids numbers. the maximum enhancement in average Nusselt number occurred at $\mathrm{Re}=5864, \mathrm{HR}=0.345$ for alt the three heat sources: the maximum enhancement in average Nusselt number is $79.4 \%$ for the first heat source, $131.7 \%$ for the second heat source. and $1.53 .4 \%$ for the third heat source.

\subsection{Comparison between present experimental and numerical results \\ 4.5.1 Comparison for obstacles inclination angle variation}

Figure (14) illustrates the variation of the average Nusselt number versus obstacles inclination angles at different Reynolds numbers for both experimental and numerical results.

The comparison is performed for the average Nusselt number of the heat sources top surfaces only because of the flow separation and reattachment at heat sources corners and sides. It is observed that at low Reynolds numbers and small inclination angle, there is a deviation between experimental and numerical results. The main reason of this deviation is that. the flow is in the transition region from laminar flow to turbulent flow. which agrees well with Wang and Vafai [5]. They indicated that in the presence of protrusions the critical Reynolds number. where the transition from laminar now to lurbulen flow is occurred, is between $500-2000$. Neveriheless. at high Reynolds numbers and large inclination angles there is a good agreement for both experimental and theorclical results. For $\operatorname{Re} \geq 2345$, there is a good agreement nt large inclination angle $(\alpha \geq 36.9)$ and for Rez 4200 there is a good agreement for all inclination angles.

Figure (IS) illustrales the velocity profile al different obstacles inclination angles. It is noticed that, for no obstacles, the inaximum velocity prolile occurs away from the heat sources surfaces but when using directing obstacles, the maximum velocity moves lowards the heat sources surfaces as the obstacles inclination angle increases. which depicts a reason for increasing the Nusselt number as inclination angle increases.

Figure (16) shows the effect of obstacles inclination angle on the stream lines. It is noticed that, in casc of no obstacles, eddies appear between heat sources but with a large circulation (weak vorticity sirength) when compared with that when using obstacles inclination angles where cddies are small (strong vorticity strengih) which enhance the heat transfer from the heat sources sides as the inclination angle increases. It is also observed that, the vorticity strength increascs as obstacles inclination angle increases.

\subsubsection{Comparison for height ratio variation}

Figure (17) shows the average Nusseh number versus height ratio at different Reynolds numbers for both experimental and numerical results.

The comparison is performed for the average Nusseli number of the heal sources top surfaces. It is noticed that the present experimental and numerical data have the same trend. For the first heat source, the variation of Nusselt number with channel height is small for both results. The experimental results agree well with the numerical resulis al low Reynolds numbers, Re22345 for the first heat source and at $R e \geq 2345$ for both second and third heat sources. As Reynolds number increases. the experimental results agree well with the numerical results for both second and third heat sources, but for the first heat source. as Reynoids number and height ratio increase. the deviation is noticed. It may be due to the separation at the heat sources corners that increases as Reynolds number increases and eross sectional area above the heat source decreases, this separation leads to a large crror in numcrical results. 
Figure (18) illustrates the velocity profile it differen: height ratios. It is cleat that, for $H R<0.27$, the effect of channel height variation on velocity profite and magnitude less than that when $H R>0.27$ which agree with the experimental results especially for smal! Reynolds numbers.

Figure (19) shows the effect of clannel height on the stream lines. It is noticed that, for small height ratios eddies uppear between heat sources but these eddies are large (weak vorticity strength) when compared with that of large height ratios. It is also observed thal. these eddies increase as height ratio increases and Reynolds number inereases.

\subsection{Pressure Drop}

Although pressure drop is considered one of the most prominent and fundamental configurations related to the electronie cooling. only a few articles reported the pressure drop caused by the protruding discrete heat sources. [20]. Figures (20) and (21) depict the variation of total pressure loss cocfficient with Reynolds number. It is clear that for no obstacles, the pressure loss coefficient decreases as Reynolds number increases which agree with Wang and Vafai [5]. As inclination angie or height ratio increases the pressure loss coefficient tends to be constant with Reynolds number. It may be due to the increasing of turbulent and pressure loss which increases as Reynolds number increases.

\subsection{Comparisons between enhancement based on increasing Reynolds number and that using obstacles angles}

Figures (22) show the enluancement of average Nusselt number with respect to the consumed power. It is observed that, for the first heat source, the enhancement of the average Nusselt number due to increasing of Reynolds number is better than when using obstacles angles for the same consumed power. On the other hand. the second and the third heat sources have enhancement of the average Nusself number when using obsiacles angles more than that due to increasing of Reynolds number for $R e \geq \$ 200$.

Figure (23) depicts that, as the height ratio increases (channel height decreases) and obstocles inclination angle is constant $\left(\alpha-36.9^{\circ}\right)$. The enhancement of the average Nusselt number due to using obstacles angles is more than that due to increasing of Reynolds number for the same consumed power.

\section{4-8 Correlating the experimental results}

From the above discussion, it is found that, both incrensing the height ratio idecreasing the channel height) and redirecting the flow lowards the heat sources surfaces and cavities betweell heat sources increase the heat trans fer coefficient. For the inclination argle variation. empirical correlations $(18)$ are obtained 10 relate average Nussels number (Nu) with Richardson number $\left(\mathrm{Gr}_{1} / \mathrm{Re}_{\mathrm{i}}{ }^{2}\right)$ and obstacles inclination angle $(\mathrm{a})$ fot each heat source as following:

$$
\begin{aligned}
& \overline{N u 1_{i a}}=57.53\left(\frac{\mathrm{Gr}_{1}}{\mathrm{Re}_{1}^{2}}\right)^{-0.26}(\cos (\alpha))^{-0.429}
\end{aligned}
$$

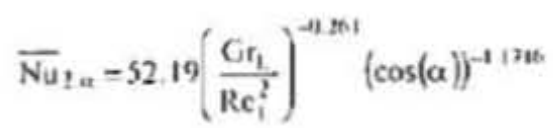

$$
\begin{aligned}
& \overline{N u v_{0}}=46.1 d\left(\frac{G r_{1}}{R e_{1}^{?}}\right)^{-\lambda m s 7}(\cos (\alpha))^{-1146}
\end{aligned}
$$

Where subscripts 1, 2, and 3 refer to the heat source number.

The above correlations are valid for; $856 \leq R e \leq 8340$. $0^{\circ} \leq \alpha \leq 53 . I^{\prime \prime}$ and $H R=0.222$. Correlation $(18)$ predicts the experimental data with an average error $=8.5 \%$ for the first heat source, and $\$ 14.2 \%$ for the second and third heat sources, respectively as shown in Figs.(24-26)

For height ratio variation, eulpirical correlations (19) are obtained to relate average Nusselt number with Richardson number and height ratio $(\mathrm{h} / \mathrm{H})$ as following:

$$
\begin{aligned}
& \overrightarrow{N u}{ }_{118}=352\left(\frac{G r_{L}}{R c_{i}^{2}}\right)^{-62587}\left(\frac{h}{H}\right)^{1000} \\
& \overline{N u}_{211 k}=1057\left(\frac{\mathrm{Gr}_{1}}{\mathrm{Re}_{2}^{2}}\right)^{-132650}\left(\frac{\mathrm{h}}{\mathrm{H}}\right)^{1,8610} \\
& \overline{N u} \text { s. }=985\left(\frac{G r_{i}}{R c_{i}^{2}}\right)^{-0.2170}\left(\frac{h}{H}\right)^{129 \pi}
\end{aligned}
$$

Correlations $(19)$ are valid for: $856 \leq \operatorname{Re} \leq 7280,0.222 \leq$ $H R \leq 0.345$ and $u-36.9^{*}$ within crror of $\pm 15.5 \%$

\section{CONCLUSIONS}

Mixed convective heat transfer and pressure drop for three protruding heal sources, moumted in a horizontal rectangular channel, are investigated experimentally and theoretically. The investigation is performed for obstacles inclination angles ranged from $0^{\circ}$ to $51.3^{\circ}$. Reynolds numbers ranged from 856 to 8340 and constant Grashof number of approximately $2.0 \times 10^{\prime}$ The investigation is extended to include the channel. height variation while the protrusion height remains constant. From this investigation, it is conducled that: 


\section{76 Mahmoud M. Awad, Gamal I. Sultan \& Waleed A. El-A wady.}

- As obstacles angle increases the heat innufer for all heat sovrces increases and give an enhancement in the average Nusselt number up to $102.1 \%$

- Decreasias the channel height increases the heat transifer and gives an enhancement in the average Nusieh nember up $10153,4 \%$

- for fies4200 and as26.5. He enhanceinem in the sverage Nusselt number is not significant while for Re > 200 a significant increase in the merage Nusel number is observed for ail inclination angles.

- For Re $\$ 2097$ and $H R \leq 0.27$ a valuable enhancement in heat iransfer for all heal sources, from $12.9 \%$ to $37.3 \mathrm{~W}$ is observed. while $n \mathrm{HR}>0.27$ the maximum enhancement occurs at Re>4200

- As be heigla ratio increases and ebuackes inclination

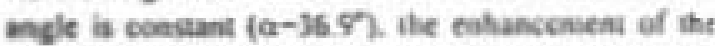
overage Nuselt nanber doc io sting obuacles angles h more than that doe 10 incrensing Reynolds numbe for the ame consumed power.

- As inclination angle or heiphit ratio increases the pressure loss coefficient tends to be contuant with Reysolds number.

- Two enoirical correlations, for each heat source, for merage Nusselt number are obitined as shown in equations (15) and $(17)$.

\section{Nomenciature}

\begin{tabular}{|c|c|}
\hline$b$ & Otwacle heigle, m \\
\hline c, & Censtant \\
\hline C. & Constanat \\
\hline $\mathrm{C}_{4}$ & Consiant \\
\hline $\mathrm{C}_{4}$ & Constant \\
\hline$f$ & Friction factor \\
\hline 5 & Gravity accelenation, mis? \\
\hline c. & Gravity accelention in y direction, $m \mathrm{~s}^{2}$ \\
\hline G. & Energy geseration due to buogancy \\
\hline$c_{\mathbf{n}}$ & Turbsience kinetic energy grentration \\
\hline H & Channel height, an \\
\hline h & Heat source height, m \\
\hline h. & Local heat transifer coefficient, W/mi't"C \\
\hline 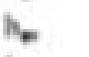 & Average heat transfer coefficient, W/m". "C \\
\hline 1 & Clectrical current, A \\
\hline$k$ & Turtulena kinetic energy, $/ \mathbf{k}_{\mathbf{k}}$ \\
\hline $\mathbf{L}$ & Heat source length in the flow dirscaine, w \\
\hline 4 & Test section length at entrance. $m$ \\
\hline$L_{4}$ & Test section lengh at exil, an \\
\hline P & Pressure. Pa \\
\hline $\mathrm{P}$, & Consamed pumping power, W \\
\hline$P_{\text {sen }}$ & $\begin{array}{l}\text { Consumed pumping power without } \\
\text { enhancernent, W }\end{array}$ \\
\hline
\end{tabular}

\section{Q Hen Aux. W/m?}

\$. Spacins betwees heat sources, $m$

S. Source term, kg "Chm's

T Temperahure. ${ }^{\circ} \mathrm{C}$

u Vebeity in $\mathrm{x}$-direction, $\mathrm{m} / \mathrm{s}$

6. $v$ Tubulent Ractuating velocities in s-direction and y-direction, espectively, $m$ h

$\checkmark$ Velncity in y-direction, avi

V Potential difference actoss heal wource. V

y Volume flow rate, m's

W Duct with, 6

x.y Canesian co-ordinates

AP Preveire drop acmss the onfice, Pa

Afoup prevsiare drop across the tes secilon. Pa

\section{Dimensionless groups}

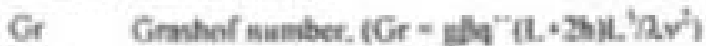

Ne Nusselt number. (Na $=\mathrm{hL}$ )

Re Reynolds numater, (puL/p)

Ri Richardson number. (GriRe?

Creek syabels

a Obatacles incliation angle, deyree

7 Coeficient of thermial expansion, $\mathrm{K}^{-1}$

c Turbulence dissipating nste, Wha

* Dintensioeless iemperature difference. "C

c Densby, kgin'

F Dyanic viscosity. $\mathrm{Na}^{2}$,

r Diflakon fackor, kgins

v Rimenutic viscosily, $\mathrm{m}^{7} \mathrm{~h}$

1. Thernal condactivity, Wima T

g. Prasdil number foe 5

o. Prandal number for $\mathrm{k}$

Si Domoin buouderies

\section{Subscripts}

in Fins heat source. obstacles angle

2a Second heat source, obutacles angle

3,a Thind hen source, obuacles ancle

1.HR Fint Meat vource, height ratio

2,HR Second heat source, height ratio

3.HR Second heat source, height ratio

a. and in Air, inlet condition

av. in average

c effective

ent enhascenent

L heat source length in the flaw direction

mas neximuan

Nim numerical

P. At coestant pecsure

turbuleut

is trea! 


\section{REFERENCES}

III J. L. SergenI and AI Krum. 1998. "Thermal Afunagemem Handbook for Elecironic assembliex". Mc(iraw-1 lill inc. New York.

121 S. Sathe and 8. Sammakia. 1998. "A Revicw of Recent Development in Some Practical Aspects of Air-Cooled Electronic Packages". Journal of Heot Transfer. Vol. 120. PP. 830-839.

[3] S. Habchi and S. Acharya. 1986. "Laminar Mixed Convection in Partially Blocked. Vertical Channel", Imt. J. Heat Mass Transfer, Vol. 29. No. 11. PP. 1711-1722.

[4] M. M. Rahman and J. Raghavan. 1999. "Transienı Response of Protnuling Electronic Modules IExposed to Horizontal Cross Flow". Imternational Journal of Iteat and Finid Flow. Vol. 20, Pp. 48.59.

IS\} Y. Wang and K. Valai. 1999. "Heal Iransler and Pressurc Loss Characterization in a Channel With Discretc FlushMounied and Protnuding Heat Sources". Fixperimentat Ileat Transfer. Vol. 12. IP. 1-16,

$|6|$ G. I. Sultan. 2000. "Linhancing Forced Convection Ileat Transfer from Multiple Protruding lleat Sources Simulating Electronic Components in a Horizontal Channel by Passive Cooling". Microelectronics Journal Vol. 31. PP. 773-779.

17) H. Iwai. K. Nakabe, and K. Suzuki. 2000. "Flow and Ileat Transfer Characteristics of Backward-Facing Slep Laminar Flow in a Rectungular Duct". Imt. J. lleat Mass Trunsfer. Vol. 43. PP. 457-471.

181 E. M. Sparrow and L. M. Hossfeld. 1984. " I: Neet of Rounding of Protnuding Edges on Ileat Transfer and Pressure Drop in a Duct". Int. J. Heot diass Iransfer, Vot. 27. No. 10. PP. 1715-1723.

$19 \mid$ B. A. Jubran and M. S. Al-Haroun. 1998. "lient Iransler Enhancement in Electronic Modules Using Various Secondary Air Injection Hole Arrangements". Journal of Heat Transfer, Vol. 120. PP. 342-347.

(I0) G. Guo and M. A. R. Sharif. 2004. "Mixed Convection i) Rectangular Cavities at Various Aspect Ratios with Moving Isothermal Sidewalls and Constant Flux Ileat Source on The Boltom Wall", International dournal uf Thermal Sciences, Vol. 43. PP. 465-475.

(III A. Dogan. M. Sivrioglu. and S. Baskaya. 2005. "Lixperimental Investigation of Mixed Convection Hear Transler in a Reclangular Channel With Discrete Heal Sources at the Top and The Botton". imernational communication in Heat and Mass Trunsfer Vol. 32. Pl $12 \$ 4 \cdot 1252$

[12] G. I. Sultan, 1999. "Mixed Convection Conling of Multiple Protruding Heal Sources in a Horizontal Channel". Aansoura Eing, Journal (AIEJ). Vol. 24. No. 3.

|13] S. V. Garimella and P. A. libeck. 1991. "Eflect of Spanwise Spacing on The Heal 'Transfer from in Array of Protruding E:Ienents in Forced Convection". Int. J. Heol Mass Transfer. Vol. 34. No. 9. PP. 2427-2430.

[16] E, M. Sparruw, S. B. Vemuri and D. S. Kadle. 1983. "Enhanced and Local Heat Transfer. Pressure Orop. and Flow Visualization for Arrays of Block-Likc Electronic Cumponents". Int. J. Heat Mass Transfer. Vol. 26. No. 5. PP. 689-699.
$|17|$ S. V. (jarimella and P. A. Fibeck. 1991. “ I:nhancement of Single Plaase C'onveclive Ileat l'ransícr lron Prolruding Fitments Using Vortes (icntraturs". Lim. J. Heat Mlass Trans/er. Vol. 34. No. 9. PP. 24,31-2433.

1181 H. W. Wu and S. W. Merng. 1999. "IIllect of an Oblique Plate on Ileal Transfer Inhanceunent of Mixed Cinvection Over Ilented Hlocks in a Ilurizontai Channel". Imt. J. Ileat Maxi Irams/er Vol 42. Pl', 1217-12.35

|19|S. Y. Kim. II. J. Sung. and J. M. IIyun. 1992. "Mixod Convection from Multiple-Iayered Boards with Cross Strcanwise Periodic Boundary Conditions". Imt. J Hea Mass Transfer. Vol. 35. No, 11. PP. 2941.2952.

|20| S. H. Kim and N. K. Anand. 1994. "Turbulent Heal Transfer Between a Series of Parallel Plates with Surface -Mounterl Discrefe Ileat Sources". Journal of lleat Tremsfer. Vol.116. PP. 577-587.

[2I] R. Sugavanam. A. Ortagn. and C., Y. Choi. 1994, "A Numerical Investigation of (onjugate Ileal 1 ransier lirum a Flush Heat Source on a Conductive Board in Laminar Channci Flow". Intersacien (inference on Thermal Phenomenom.

\{22\} W. Nakayama. And S. If. Park. 1996, “Conjugate Heal Transfer from a Single Surface-Muunted 13lock to Forced Air Flow in a Channei". Journal of Heat Trans/er, Vol. 118. PP. 311-30\%.

$|23|$ P. N. Madhavan and V. M. K. Sastri. 2000. " Conjugate Natural Consection Cesoling of Protruding lleat Sources Mounted on a Subsirate Placerl Inside an tinclosure: a Parametric Situdy". ('omput. Whothods Aly)/ Mecil, Lingry. $188 \mathrm{PP} .187-202$.

|24] S. V. (iarimella and P. A. liibeck. 1990. " Heat Trunsler Characteristics of Array of l'rolruding lilements in Single Phase Forced Convection", Im J. Heen Alass 7ransfer. Vol. 33. No. 12. PP. 2659-2064.

[25] H. Bhowmik. C. P. Tso, K. W. Tun, and F. I.. Tan. 2005. "Convection Ileat Transfer Irom Discrece liew Suurees in a Liquid Cooled Rectangular Channel". Applied Thermal Engineering. Vol. 25. Pl. 25.32-2542

[26] C. P. Tso. K. W. Thto, and G. P. Xu. 2000. " Flow I3oiling Critical I leat lilus of' lic-72 Irom Flush-Mounted and Prolruded Simulated Chips in a Vertical Rectangutar Channel". Internatiemeal jeurnal of Aultiphase Flow: Vol. 26. PP?. $351 \cdot 365$.

|27| II. Bhowmik and K. W. ТА. 2005. "Study of Transien Forect Convection Ileal I ramsler lirom Discrete Ileal Sources in a $\mathrm{Fe}-72$ Ciooled Vertical Channel". internutionat Journat of Thermal Sciences. Vol. 44. PP. 499.505.

|28| FI.U1ENT version 6.1. 2003. "user's Hamal Cinide".

[29] S. V. Patanker. 1980. "Numericul Heai Trunsfer and thisl Fitom". Meciraw-tlill. New York. 
M. 78 Mahmoud M. Awad, Gamal I. Sultan \& Walced A. El-Awady.

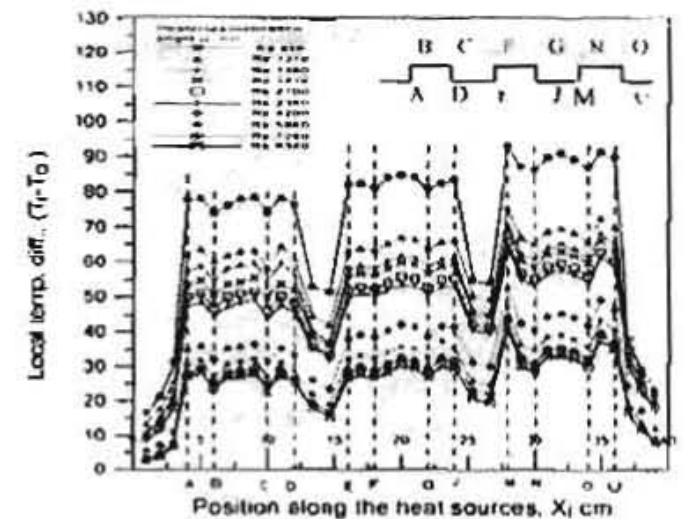

Fie. 4 Variation of local surface temperature difference

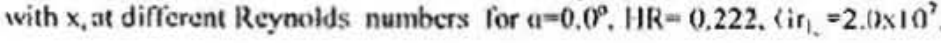

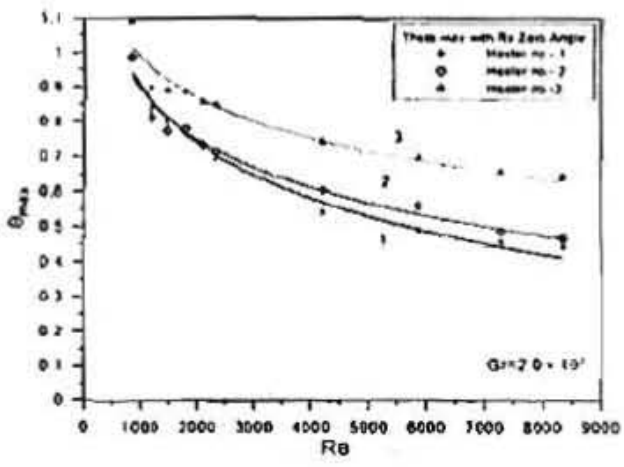

Figure 5. Variation of maximum surface temperature of heal sources with Reynolds number for $\alpha=0.0^{\circ}$. $H R=0.222$.

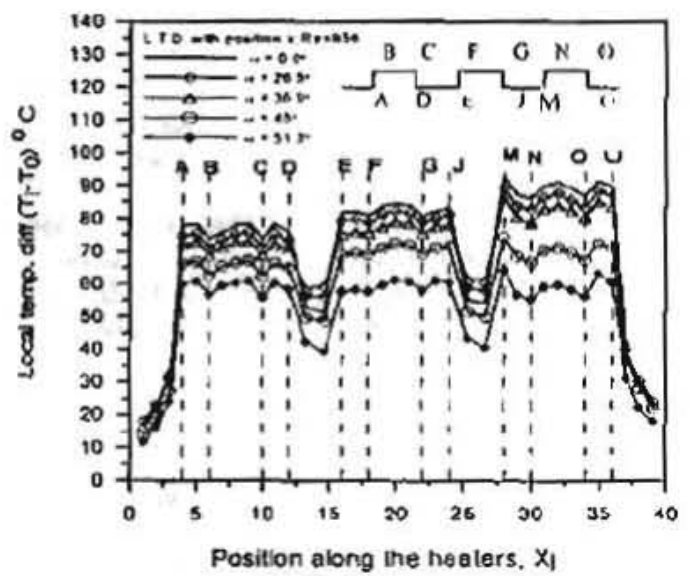

(a) $\mathrm{Re}=856$.

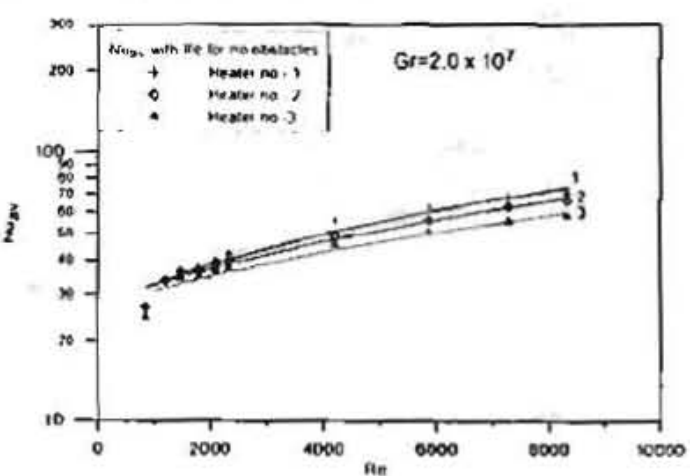

Figure 6 The average Nusselt number of heal sources versus Reynolds number for $\alpha=0.0 . H R=0.222$.

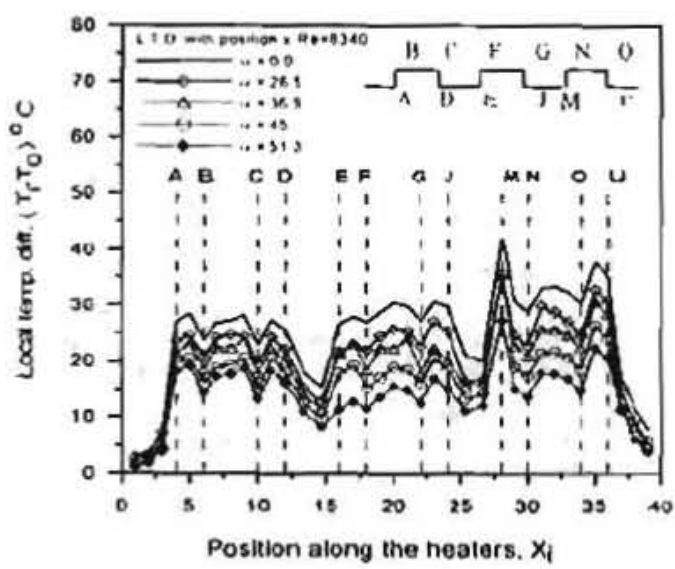

(b) Re $=8340$

Figure 7. The local surlace temperature dilference versus $x_{i}$ at difierent Reynolds numbers and inclination angles. $M R=0.222$. $\left(\mathrm{ir}_{\mathrm{L}}=2.0 \times 10^{7}\right.$

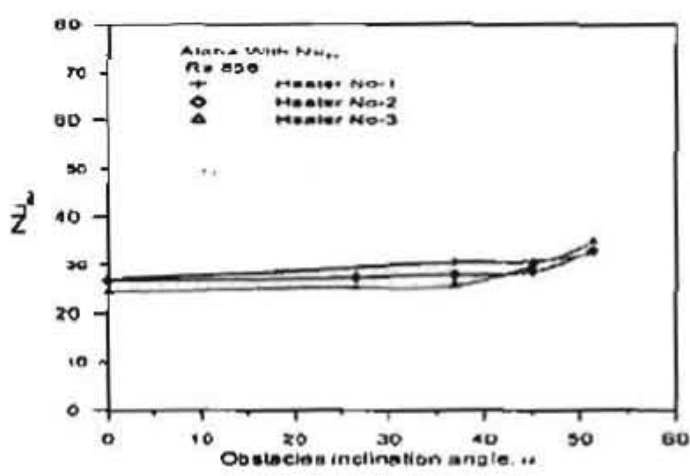

(A)

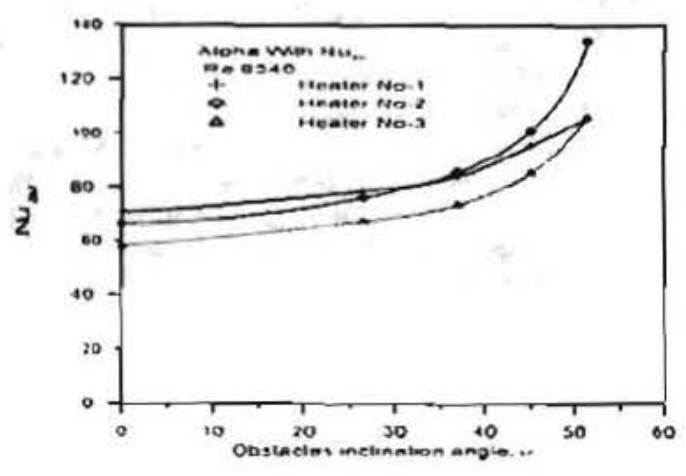

(B)

Figure 8. The average Nusselt number of the three heat souress versus obstacicx inclination ang/c at different Reynolds numbers, $\mathrm{Gi}_{\mathrm{L}}=2 \times 10^{7}, 1 \mathrm{RR}=0.222$. 

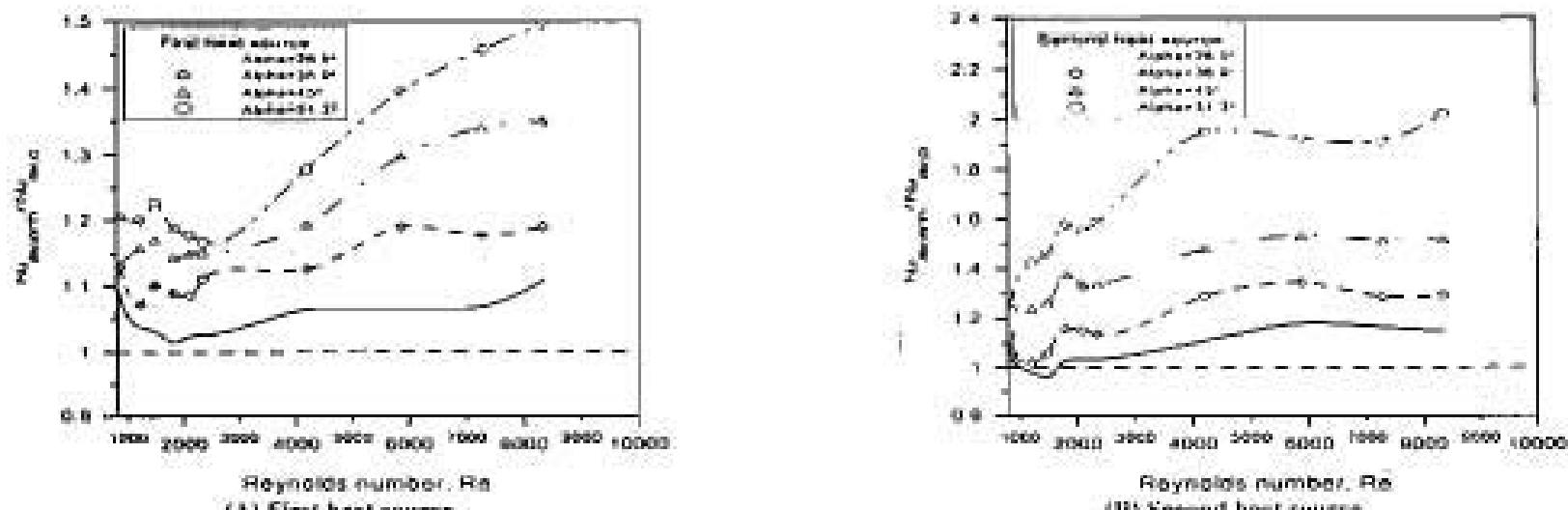

(A) First (B) Sietond heat sutures.

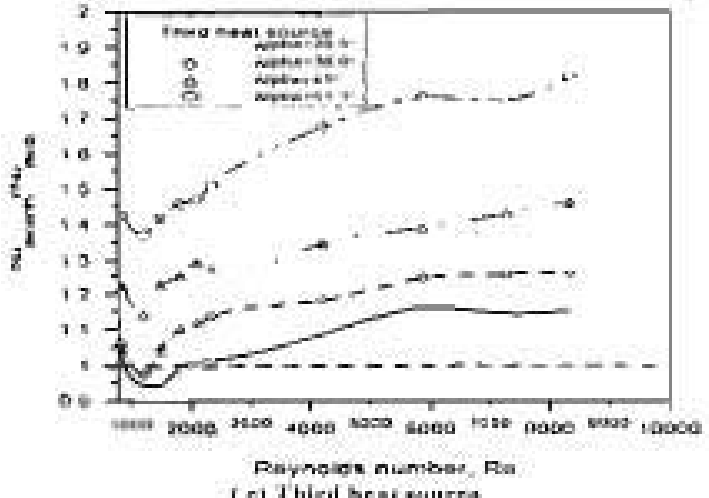

[ c] Third he ait siure

Figure 9. Enhancemen! ralio of the average: Nusscll number worsus Reynollds mumber an different obsiackes inclinaion angles. $\mathrm{Gr}_{\mathrm{c}}=2 \times 107 . \mathrm{HR}=0.222$.

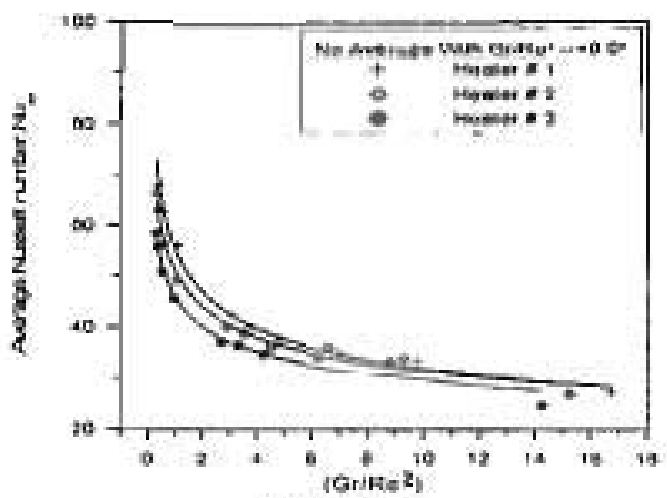

(A) $\operatorname{encot}$.

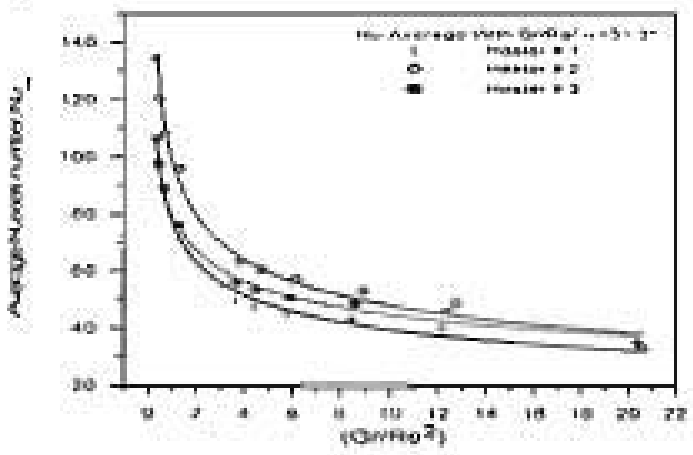

(if) $=3515$

Figurc10. Average Nusselh number of the heat sources versus Richandson number for difr. obstacles inclination angles. $H K=0.222 . \mathrm{Git}_{t}=2.0 \mathrm{~h} 10^{7}$.
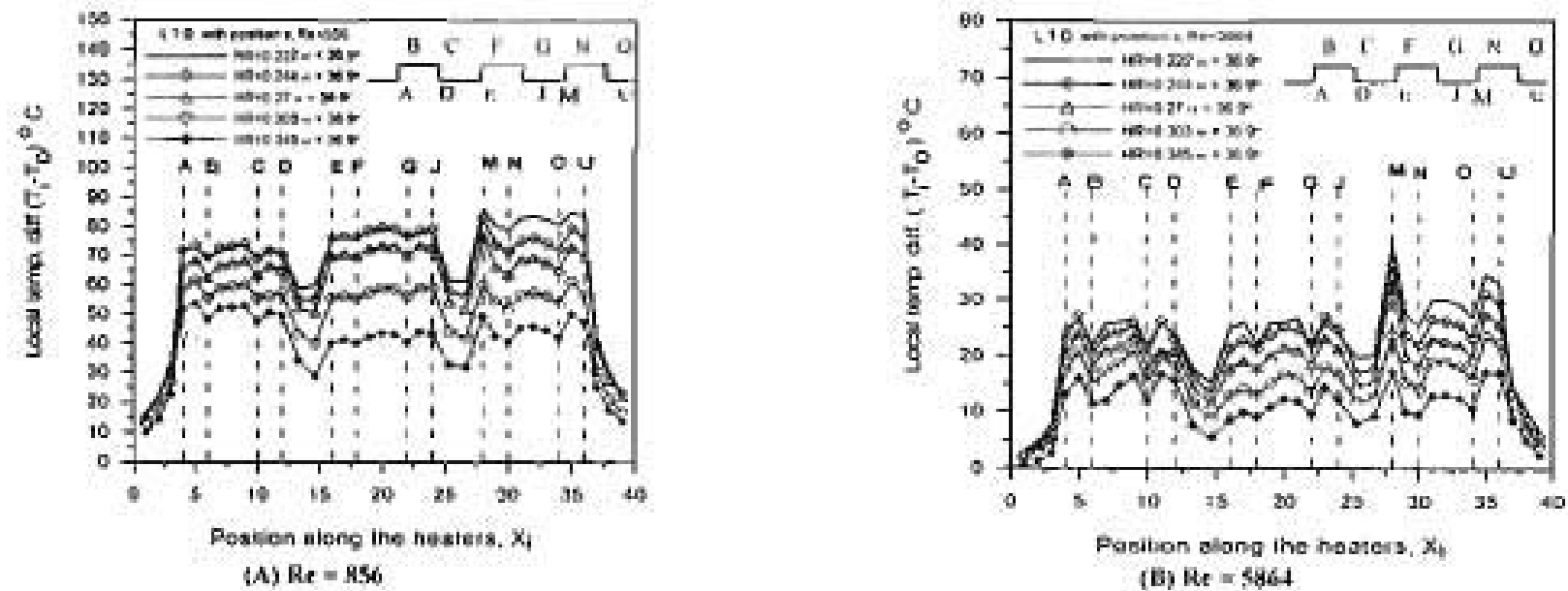
and height ratio at fixed inclination angle of $36,9^{\circ} . \mathrm{Gr}_{4}=2.0 \times 10^{7}$ 
M. 80 Mahmoud M. Awad, Gamal I. Sultan \& Walced A. El-Awady.
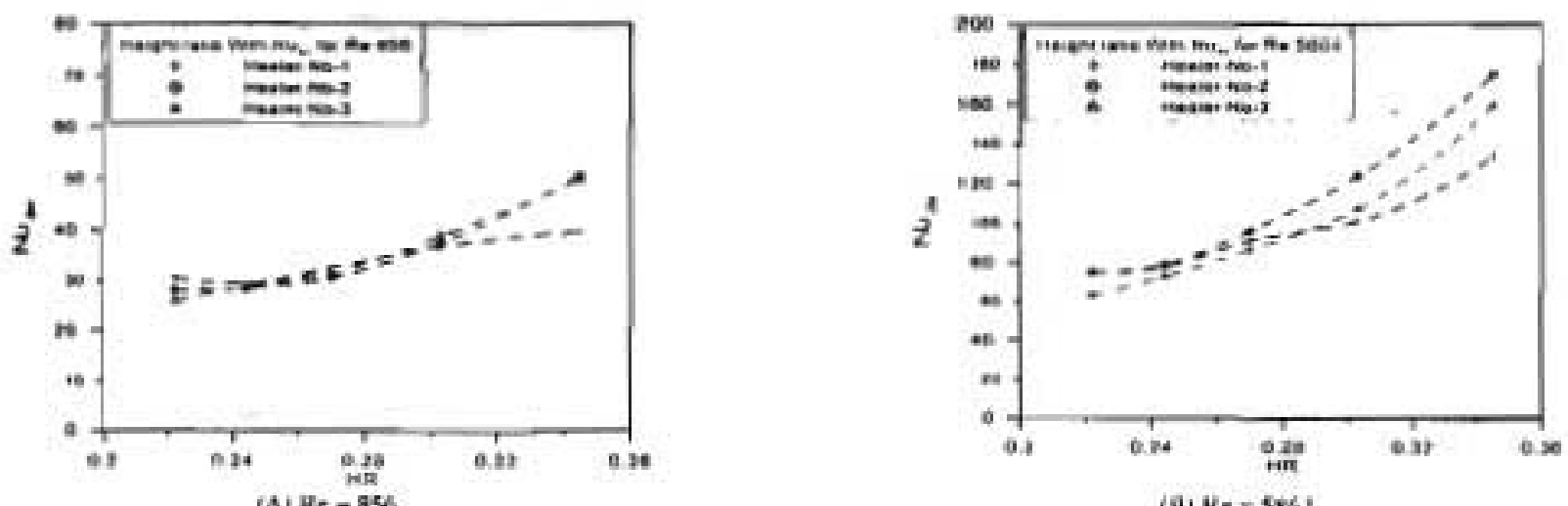

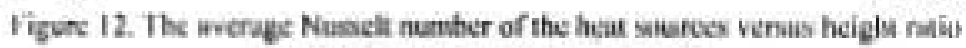
at dirf, Reynolds mumhers, ive $36, \sigma^{\circ}$

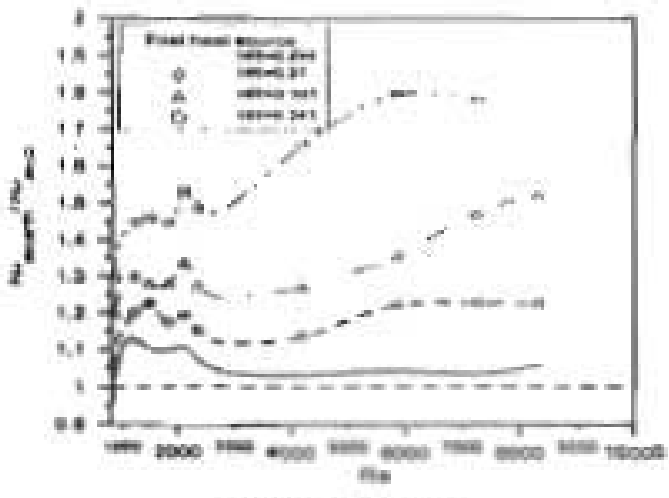

(A) Firat best sourte

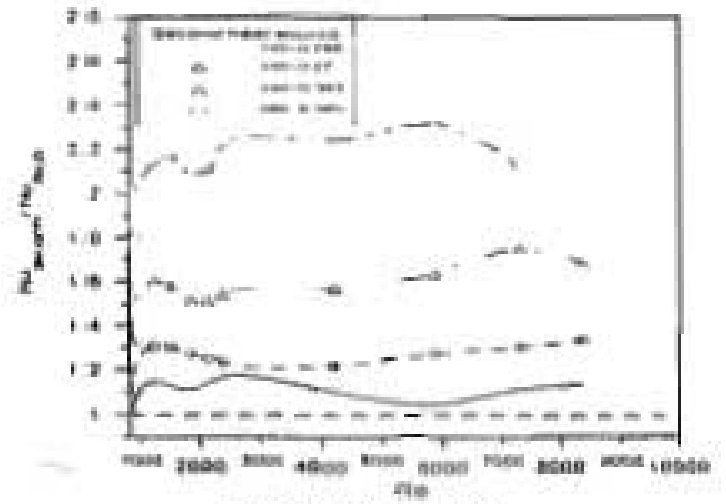

(b) Secead houl wares

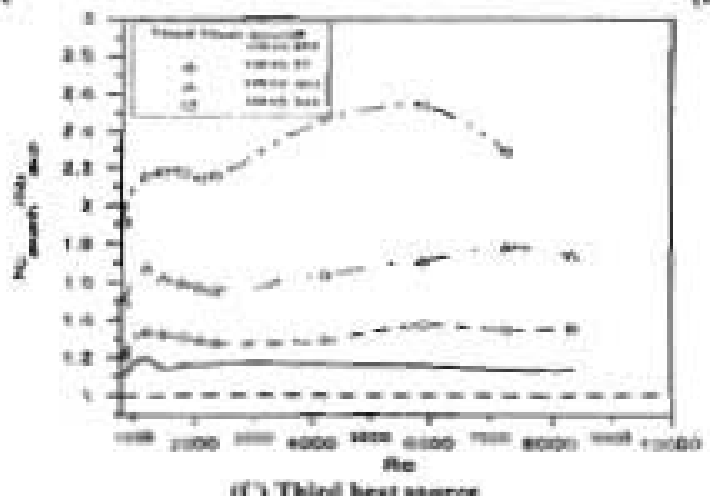

Fieure 13. Enthancement matio of the averape Nusuch number wones Reynolds eumber at difleren heights ration. $u=36, \%$
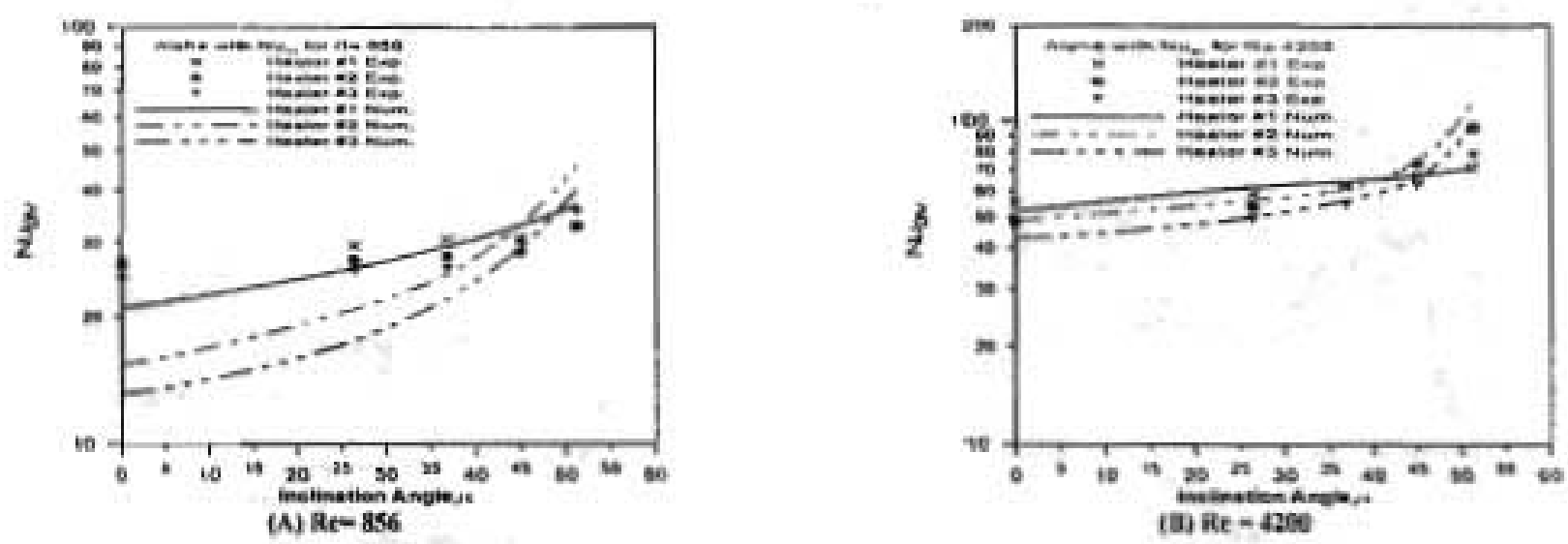

Figure 14. Camparisen between experimenial und mancerieal mealle fise the averuge Nussclt number of the beat apurces wersas indination aeple it diflerem Reyunlats mumbers. 


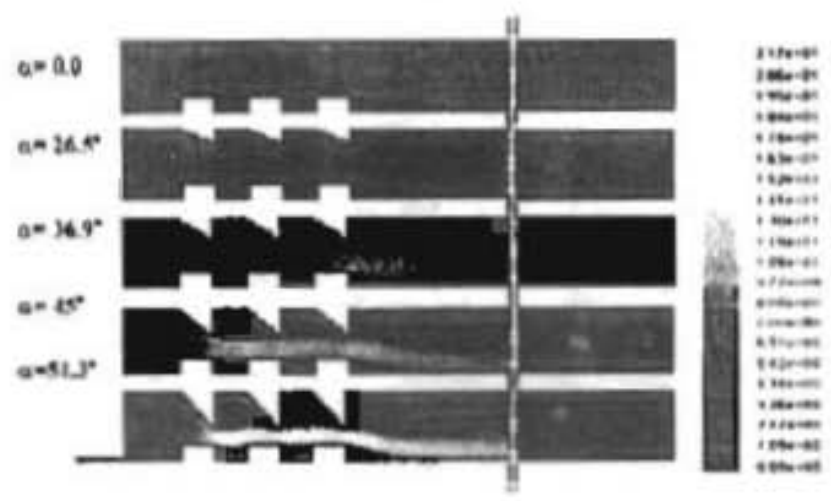

Figure. is Velocity distributiun (mvs) for Re $=8.140 \mathrm{nt}$ diffenent incliaation angels.

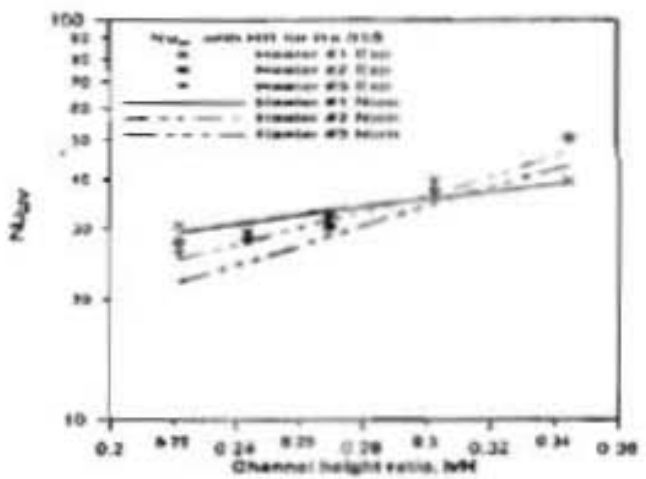

(A) Re $=8 \%$

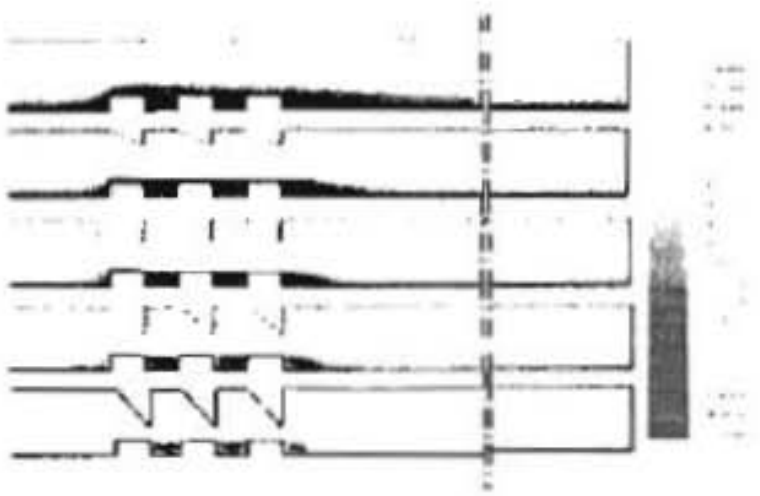

Figure 16 Sireim function distrihution (ke/s) for $R c=8344$ ai diffieront inclination avech.

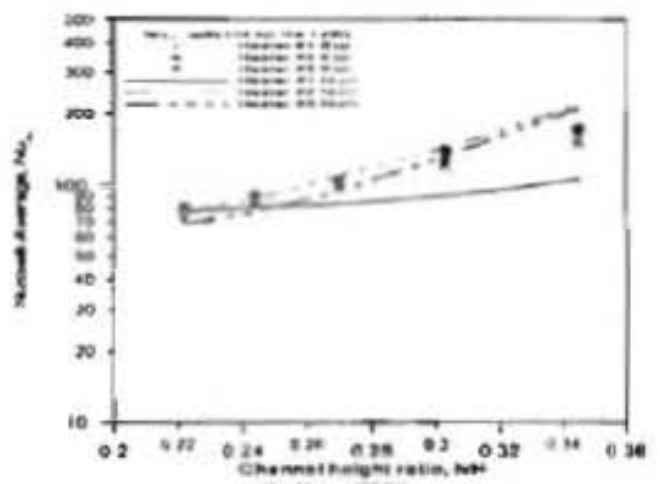

(a) $\mathrm{Ke}_{\mathrm{r}}=72 \mathrm{ka}$

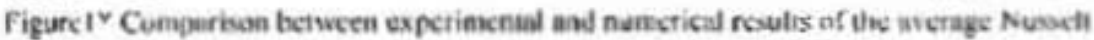

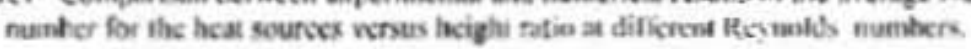

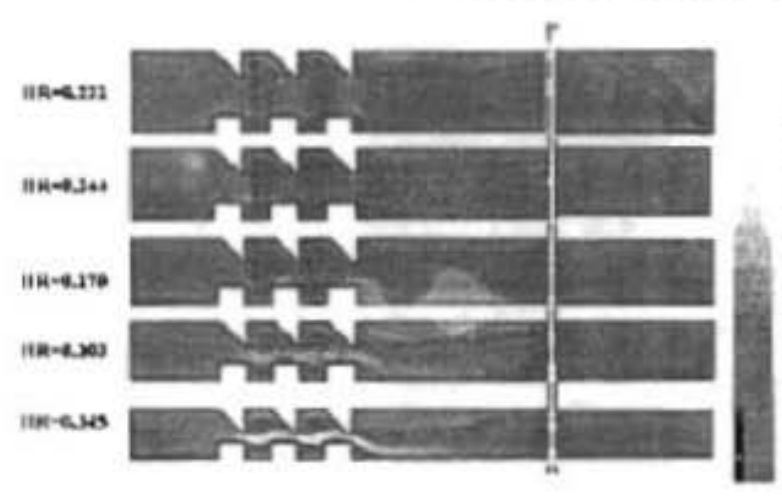

Pig 18 Velocity dietributian for Re=7280 mis at difierent heigh mubs

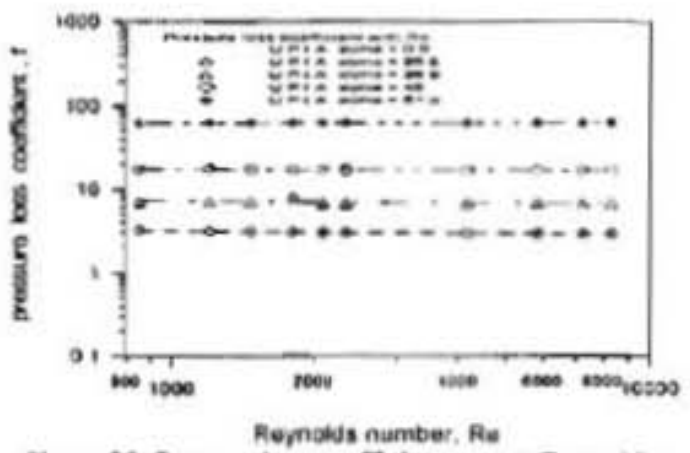

Figure 20. Prosure loss coeficient versus Reynolds nunber at difterent inclinalion angles (numerical results).

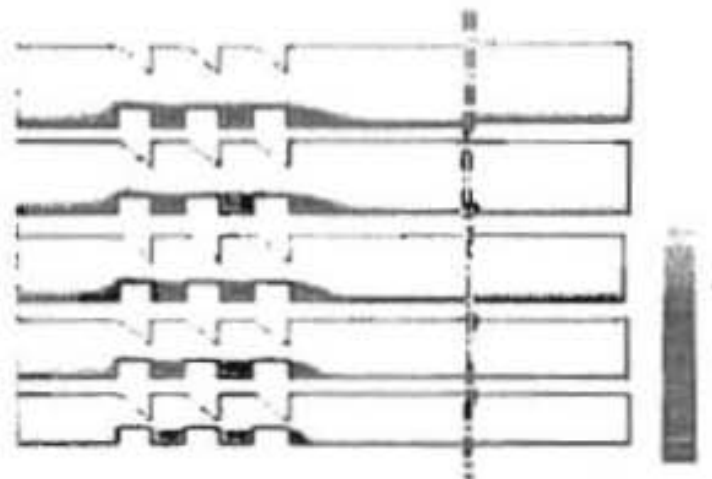

Pigure 19. Sircam functiun (ky/s) distribution for $\mathrm{Re}=72 \mathrm{Xt}$ at difieneal height raticks.

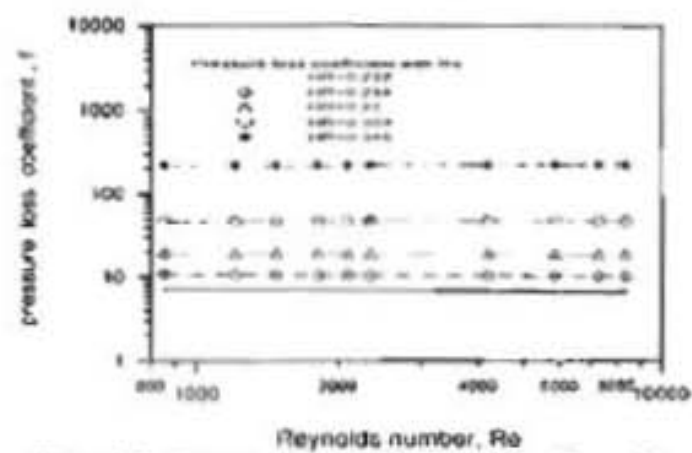

Figurs 21 Irresure loss cocmicient versus Reynolds number at dillerint heighi ratios (numeticai nsulis) 
M. 82 Malimoud M. Awad, Gamal 1. Sultun \& Wuleed A. El-Awady,

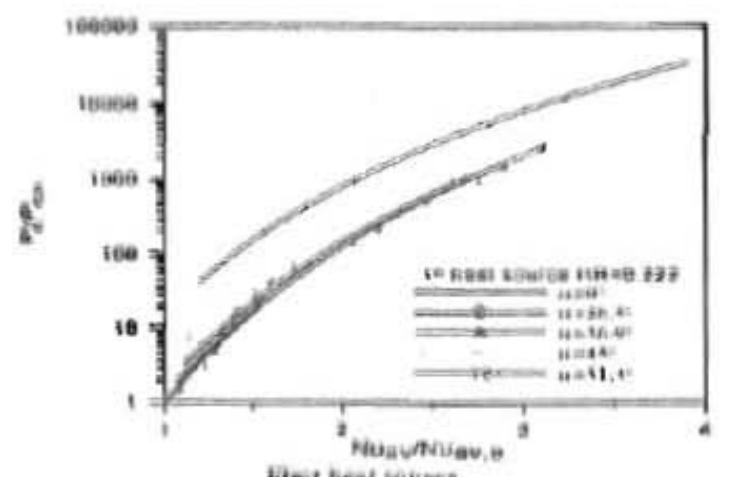

Firit heal sourse
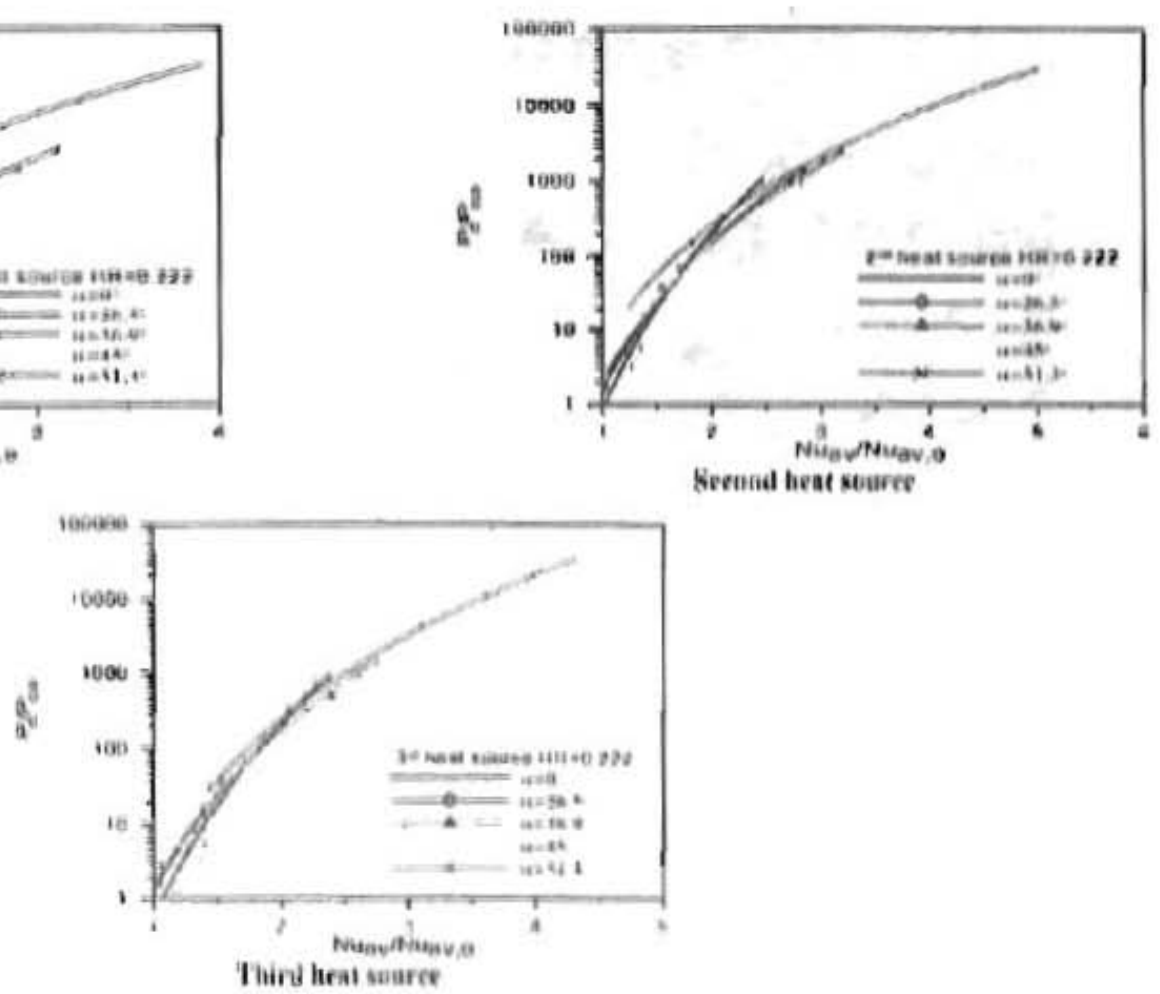

Figure 22. Consumed powir fatio venus avenge Nuwolt number. ratio at dilferent shelaedes inclination anplex.

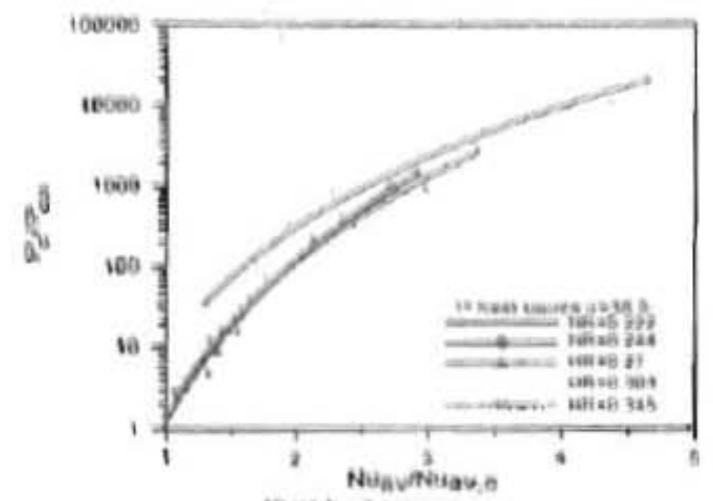

First heat seiree

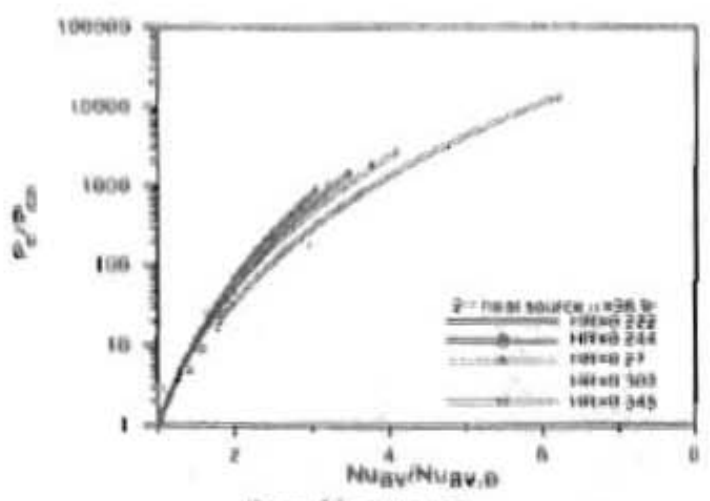

Necoed heat searee

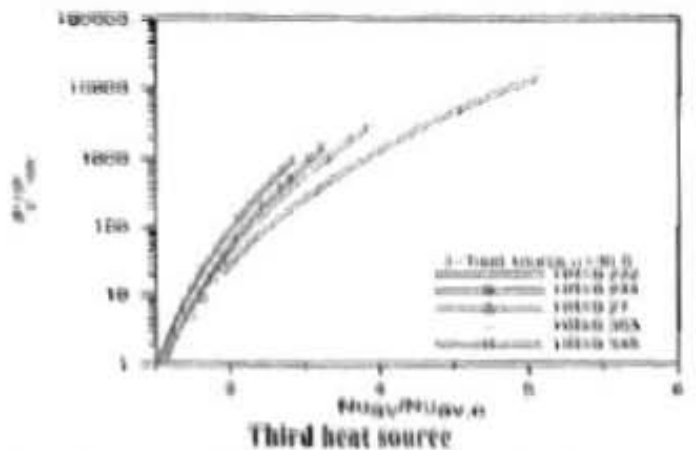

Pigure 2.1. Consumed pows natio verus avoruge Nussett aumber matio at dillerent heipht nutios. 


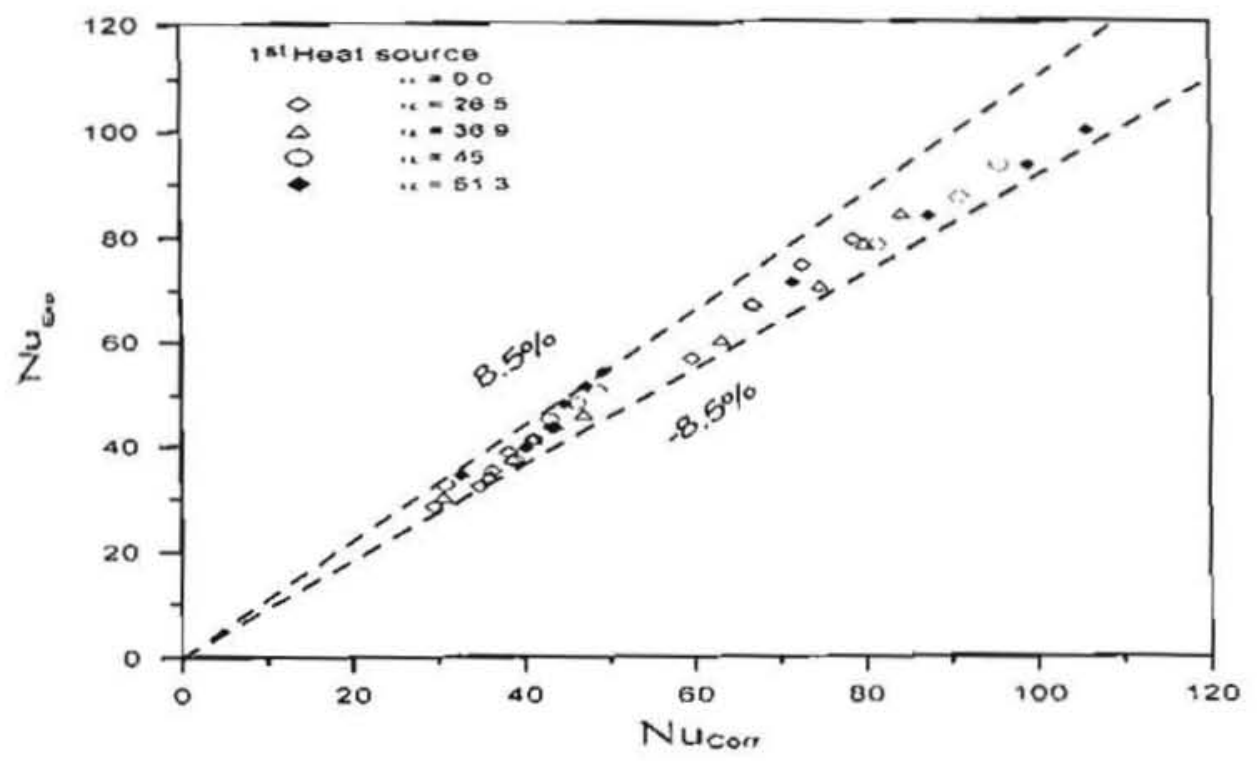

Figure 24 Deviation of experimental results of Nusscll number from correlations (18) lor the list heat stource.

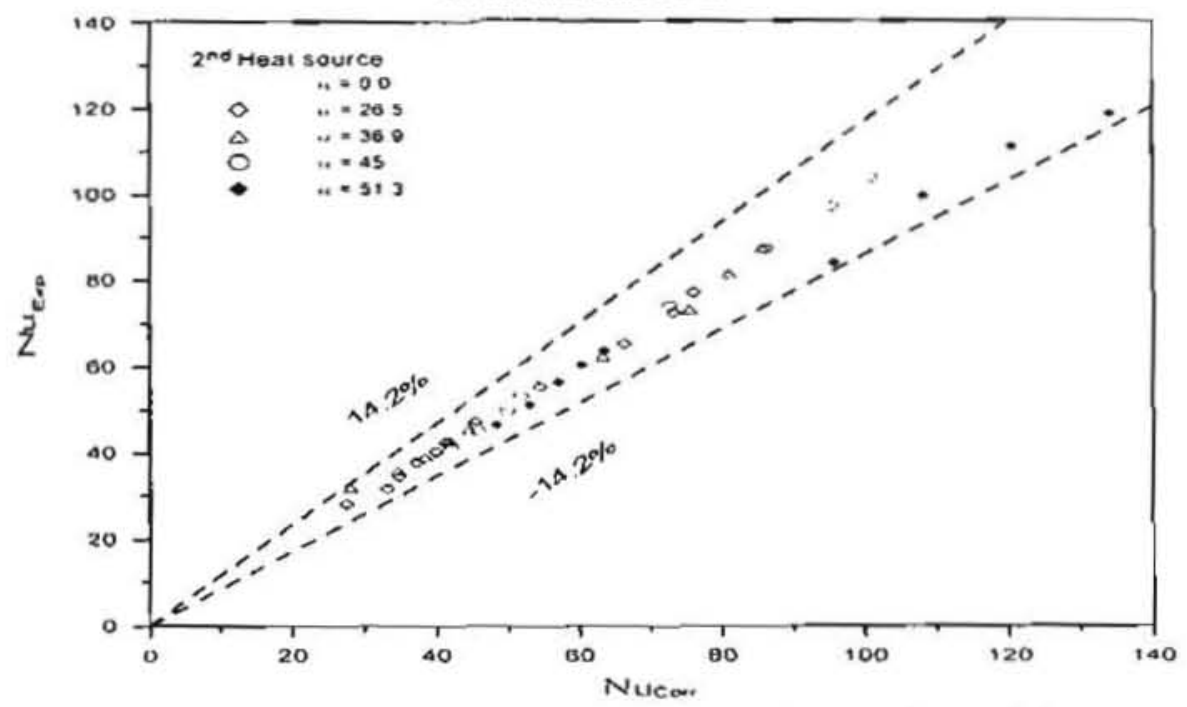

Figure 25 Deviation of the experimental results of Nusscll number from llic correlations (18) for the second heat sourc:.

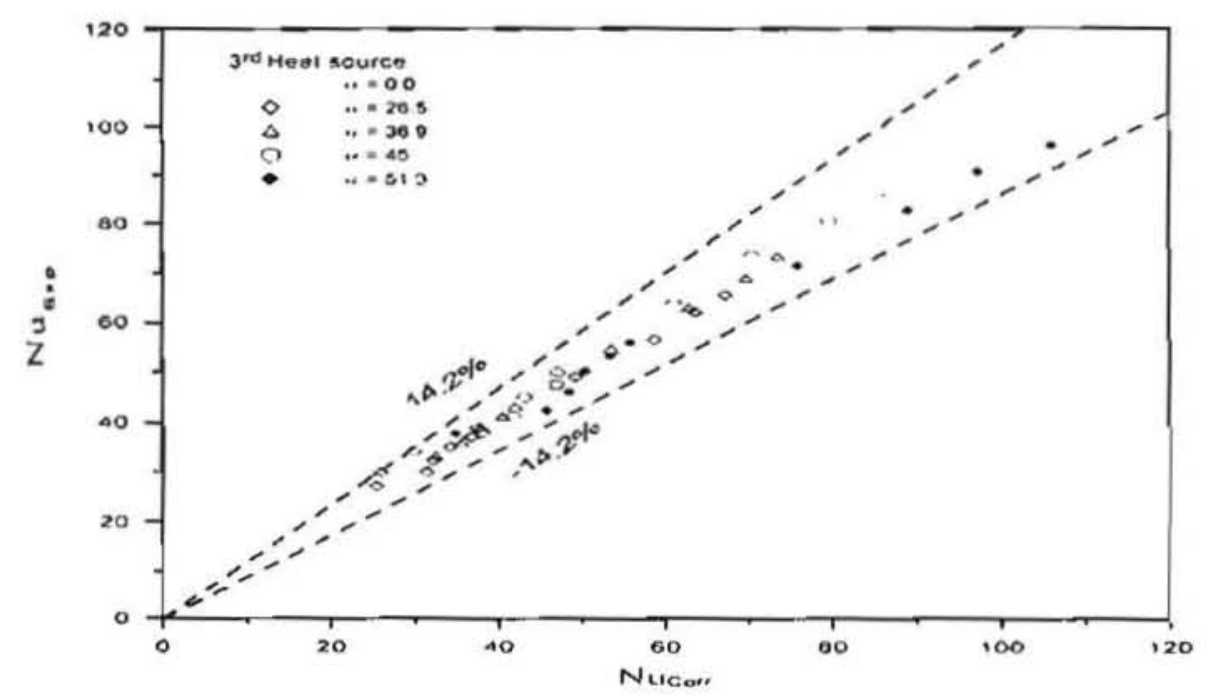

Figure 26 Deviation of the experimental resulis of Nusselt number from the correlations ( I 8) for the third heat source. 